\title{
Ocean control of the breeding regime of the sooty tern in the southwest Indian Ocean
}

\author{
Jaquemet S. ${ }^{1 *}$, Le Corre M. ${ }^{1}$ \& Quartly G.D. ${ }^{2}$
}

1: Laboratoire ECOMAR, Université de la Réunion, Ile de la Réunion, France

2: National Oceanography Centre, Southampton, Empress Dock, Southampton, Hants, UK

\begin{abstract}
:
Food availability, which is often seasonal, is regarded as a key factor in the breeding success of seabirds. In oceanic tropical areas, the resources are mostly patchy and ephemeral at the surface, and the seasonality is less marked than at higher latitudes. Such a situation influences greatly the breeding strategies of the oceanic seabird species. We conducted a comparative study of the breeding phenology of the sooty tern (Sterna fuscata) in relation to the local and regional oceanographic conditions around the four major colonies (Europa, Juan de Nova, Lys and Bird Islands) of the southwest Indian Ocean. Over the 1997-2003 period, around all the studied locations, the sea-surface temperature (SST) and the chlorophyll concentration in the Mozambique Channel and the Seychelles area showed clear seasonal differences related to the southern climate and the monsoon phenomena. The breeding activity is synchronized at each studied colony, but the timings are very different. Seasonal reproduction occurs in austral winter at Europa and Bird Island and in austral summer at Juan de Nova; at Lys Island the reproduction is non-seasonal. For the seasonal colonies, there is a large monthly change in SST just before the beginning of reproduction, which is a proxy indicating the annual phytoplankton bloom. This variation is accompanied by the development of oceanic features such as fronts that favour aggregation of prey, and may also play an important role in the presence of schools of surface tuna, which are very important for the foraging success of sooty terns. Conversely, around Lys Island the seasonal variations of the marine environment do not lead to pronounced development of oceanic structures, and consequently, the longer-lasting phytoplankton bloom could explain the non-seasonal breeding regime there. Further studies will help discern the advantages and disadvantages of seasonal and non-seasonal reproduction regime in response to unpredictable fluctuations of the marine environment.
\end{abstract}

Key Words: Seabirds, Sterna fuscata, breeding phenology, SST, Chlorophyll, Mozambique Channel, Seychelles Archipelago, southwest Indian Ocean

\section{Introduction}

Since breeding is energetically costly, seabirds should attempt to initiate breeding at a time that ensures optimal overlap between nutritional requirements and food availability (Lack 1968, Frederiksen et al 2004). Because individuals are tied to their colony while breeding, the distribution and abundance of food within their foraging range are the key factors affecting reproductive success (Chastel et al 1995), colony size (Cairns 1992, Parrish et al 1998, Ainley et al 2003) and breeding season (Le Corre 2001). Hence, seabirds may be able to rely on proximal environmental factors of their marine habitat, which will allow them to initiate reproduction at the best time to coincide with the largest availability of prey and ultimately optimise their breeding success.

In long-lived species like seabirds, the breeding regime is mostly seasonal and related to the seasonal availability of prey (Ainley \& Boekelheide 1990, Hamer et al 2002). At polar and temperate latitudes, the synchrony between food supply and breeding schedules is often forced by the well marked seasonality of the environment (Schreiber 1980). Several studies have already demonstrated correlation between spring temperature and breeding phenology, 
when prey are sufficiently abundant to support high predation rate and to limit competition (Martin 1987, Lindberg et al 1997, Ainley \& Boekelheide 1990). Availability of prey, consequently, is regarded as a nearly indispensable condition for individuals to succeed in reproduction.

At high latitudes, the photoperiod plays a critical role in the decision to initiate and terminate breeding because it is a highly reliable factor, which is not affected by local environmental conditions (Schreiber 1980, Wingfield \& Kenagy 1991). The length of the day is correlated with specific seasons and associated with specific foraging conditions (i.e., availability of prey). Hence, the photoperiod could be considered as the ultimate factor driving reproduction, with local environmental factors like the temperature and food availability being important proximal cues to adjust the timing of reproduction (Schreiber 2002).

In tropical zones the marine environment has, for a long time, been believed to have little seasonality and little productivity compared to higher latitudes (Ashmole 1971). This widely held notion is largely not supported anymore (Shea \& Ricklefs 1996, Le Corre et al 2003), although seasonality is less marked than at higher latitudes. Similarly, the annual changes in photoperiod are small at low latitudes. Interestingly, many bird species show annual reproductive cycles that often resemble the seasonal reproductive strategies of temperate birds (Wikelski et al 2003, Beebe et al 2005). The causes, however, are not very well understood. In tropical seabird species the relation between initiation of reproduction, hormonal secretion and photoperiod is weak, and other local environmental factors like sea surface temperature (SST) could trigger breeding activity (Lormée et al 2000). Especially, in places where huge seasonal changes of the marine environment like monsoon or seasonal upwelling occur, seabird populations show breeding patterns similar to those that exist at higher latitudes (Harrison et al 1983, Le Corre 2001).

In the southwest tropical Indian Ocean, although some seabird species have nonseasonal breeding periods (Diamond 1976), for most of them breeding activity is seasonal. At the Seychelles Archipelago (Feare 1976, 1981; Ramos et al 2002), at Aldabra Atoll (Diamond $\&$ Prys-Jones 1986) and at Europa Island in the southern Mozambique Channel (Le Corre 2001, Le Corre et al 2003), most of the seabirds breed seasonally. The breeding seasons depend on various environmental factors being favourable for reproduction. However, no study has clearly identified the changes of the marine environment that generate these favourable conditions for seabirds, although Le Corre (2001) noted, at Europa Island, a match between the presence of cold subtropical waters in the vicinity of the island and the breeding periods of some species, among which is the widespread and superabundant sooty tern (Sterna fuscata).

We study the timing of reproduction of the sooty tern in 4 major colonies of the southwest Indian Ocean: three in the Mozambique Channel and one in the Seychelles Archipelago (Figure 1a). From south to north, we considered Europa (22 $20^{\prime} \mathrm{S}, 40^{\circ} 22^{\prime} \mathrm{E}$ ),

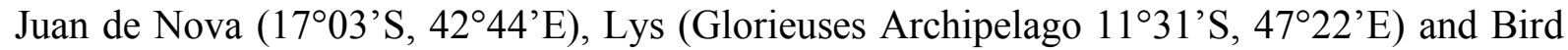
Islands (Seychelles Archipelago, 3 ${ }^{\circ} 53^{\prime} \mathrm{S}, 5^{\circ} 12^{\prime} \mathrm{E}$ ). These islands are oceanic and are the regular breeding locations of several hundreds of thousands of breeding pairs of sooty terns (Feare 1976, Rocamora \& Skerrett 2001, Le Corre \& Jaquemet 2005). Within this latitudinal range, breeding seasons are very different, with austral winter reproduction on Europa (Le Corre 2001) and Bird Island (Feare 1976, 1981, Rocamora \& Skerrett 2001) and summer reproduction on Juan de Nova (Le Corre 2001, Le Corre and Jaquemet 2005). Finally, at Lys Island, sooty terns do not breed seasonally (Le Corre and Jaquemet 2005). These 4 islands are in the same hemisphere and not very distant from one another, so why are there such differences in the breeding season of the sooty tern between these sites?

In several cases, the prey abundance around breeding locations is correlated with the reproductive biology of seabirds (i.e. Anderson et al 1982, Cruz \& Cruz 1990). Similarly, the abundance and availability of prey have often been related to fluctuation of SST driven by 
climate variability (Hyrenbach \& Veit 2003, Peck et al 2004), such as the seasonal cycle (Spear et al 2001). In tropical areas, surface enrichment in chlorophyll leads to a higher abundance of zooplankton and flying fish (Piontkovki and Williams 1995), which are largely preyed on by tropical birds. Since our studied colonies are very large and the breeding activity is highly synchronized within locations, the food requirements by colonies are enormous, while the foraging is temporally and spatially restricted for the breeding adults. We hypothesize that, except at Lys Island, there should be cyclic and predictable oceanic forcing around the breeding sites that largely increase the availability of food and lead to favourable reproductive conditions. Hence, the aim of this study is to investigate which environmental factors could drive the breeding regime observed in the different colonies of sooty terns in an area where the seasonal photoperiodicity is weak. For this purpose, we examine the temporal relation between the breeding phenology of the birds and the variation of the local marine environment. We focus on the SST and the chlorophyll concentration around the colonies to test whether these parameters could indicate changes of the marine environment that lead to an increase in the food availability for birds. Finally, we try to relate the local conditions observed around the colonies to the general oceanic forcing in the southwest Indian Ocean that may be responsible for the favourable changes for seabirds and could explain the differences in the regimes of reproduction.

\section{Currents and upwelling in study area}

We focus our analysis on the tropical southwest Indian Ocean and more precisely on the Mozambique Channel and the Seychelles area. Oceanographic conditions in both of these regions are highly influenced by the South Equatorial Current (SEC), itself seasonally varying in location and in intensity in response to the monsoon phenomenon (Piton \& Magnier 1976, Donguy \& Meyers 1996). After it reaches the East Madagascar coast at $15-20^{\circ} \mathrm{S}$, the SEC divides, with one component, the North Madagascar Current, flowing around the northern end of Madagascar (Swallow et al 1988) and then branching when reaching the Comoro Archipelago. The southern branch of this feeds the flow southward through the Mozambique Channel, whilst the northern branch, known as the East African Coastal Current, feeds the Equatorial Counter-Current or, in austral winter, reaches the Somalia Upwelling (Donguy 1974, Marsac 1992).

Hence, the circulation of the Mozambique Channel is mainly derived from the SEC and has a dominant southward flow, along the African coast. The Davie Ridge $\left(17^{\circ} \mathrm{S}\right)$, however, separates the channel into two distinct parts with very different circulation systems. In the northern part the circulation is dominated by a large anticyclonic gyre (Donguy \& Piton, 1991, Schouten et al., 2003) that is limited to the south by the narrows of the channel. A number of deep anticyclonic eddies have been found along the Mozambican coast (de Ruijter et al., 2002). They appear to be generated by the pinching off of the instabilities of an eastward current that penetrates temporally through the gap at $17^{\circ} \mathrm{S}$ (Ridderinkhof \& de Ruijter 2003). A mooring across this constriction has revealed 4 to 5 eddies per year (Ridderinkhof \& de Ruijter 2003). Schouten et al. (2003) picked up a similar frequency for the anticyclonic eddies propagating poleward along the Mozambican coast. Quartly \& Srokosz (2004) showed that these features often have a pronounced ocean colour signature as they entrain productive waters from the coast and advect them into the centre of the channel. In addition the southern part of the channel, in austral winter, is penetrated by subtropical upwelled waters (Stequert \& Marsac 1986) and cyclonic eddies generated by the East Madagascar Current (Di Marco et al 2002, Quartly \& Srokosz, 2004).

The Seychelles Archipelago consists of numerous islands and banks that strew the current system constituted by the SEC and the Equatorial Counter-Current. These currents are present all year round, but their boundary, which is a divergence zone, varies in latitude between $6-7^{\circ} \mathrm{S}$ in austral summer and $9-10^{\circ} \mathrm{S}$ in winter (Piton \& Magnier 1976). To the 
northwest of the Seychelles, in austral winter, the southwest monsoon promotes the upwelling off Somalia and induces a transport of coastal African waters towards the Arabian Sea. These productive upwelled waters from the East African coast generate a large increase in the chlorophyll concentration that extends up to north of the Seychelles.

\section{Data and analysis}

\subsection{Sooty tern breeding seasons}

We estimated laying dates on Europa $(1995,2002,2003)$, Juan de Nova $(2002,2003)$ and Lys $(2003,2004)$ Islands by determining the age of randomly selected chicks from measurements of wing length using the growth curve of Feare (1976) and assuming a mean incubation period of 28 days (Schreiber et al 2002). Seychelles data were from Feare (1976) on Bird Island, one of the largest and more seasonal sooty tern colonies of the archipelago (Feare 1976, Feare 1981, Rocamora and Skerrett 2001).

\subsection{Surface oceanographic conditions}

We used sea-surface temperatures (SST) and chlorophyll concentration in a $500 \mathrm{~km}$ radius circle centred on each breeding site, assuming that this is the maximum foraging range of breeding sooty terns (Flint 1991). The SST data were obtained from the IGOSS database (http://ingrid.ldgo.columbia.edu) from January 1997 to December 2003. Although the chlorophyll concentration changes seasonally in response to the cycle of environmental forcing, the distribution of phytoplankton is very inhomogeneous. This is manifested by pronounced phytoplankton growth along the coasts (Figure 1b) prompted by local upwelling of nutrients or riverine input. Assuming that terns can adopt an optimal foraging strategy, we determine the appropriate measure of productivity of the environs by the 90th percentile of the chlorophyll a within $500 \mathrm{~km}$ of the island. This is determined from a composite of measurements for each fifth of a month, and the median of these measurements taken as an indicator of the peak productivity within the region. Thus, for example, a high productivity is determined for Juan de Nova (Figure 2), as a sizeable part of the Madagascar coastline lies within reach of the tern colony on that island. The productivity determined for Europa, on the other hand, is much lower but has significant short-term (weekly) variability because of the pronounced effects of ephemeral events causing the advection of chlorophyll into mid channel, either from the west coast of Madagascar (Figure 1b) or, more commonly, from the Mozambican coast (Quartly \& Srokosz, 2004). Zubkov \& Quartly (2003) showed that in this region the ultraplankton (those ranging in size from $0.2 \mu \mathrm{m}$ to $5 \mu \mathrm{m}$ ) were composed principally of the eukaryotic algae Synechococcus and Prochlorococcus in equal proportions. However, whilst the abundance of Synechococcus related closely to the satellite measurements the abundance of Prochlorococcus was not easily determined from satellite data. Thus changes in phytoplankton composition may not always be reflected in satellitederived values of chlorophyll.

\subsection{Detection of changes in trends}

We firstly analyse the monthly values of SST and chlorophyll concentration over the period 1997-2003 to identify the temporal variability of these parameters and describe the oceanic conditions around the colonies during breeding seasons. We use the time lag in the breeding peak between two successive seasons to evaluate the seasonality of the breeding on the different islands. Then we correlate the local trend changes (monthly) in the time series of SST and chlorophyll concentration with the laying dates by using the cum-sum method (Ibanez et al. 1993). This method, which calculates the sum of the deviations of all individual data from the mean of the series, allows us to detect dates of the changes of trend in the time series. 


$$
\mathrm{S}_{\mathrm{p}}=\sum_{\mathrm{i}=1}^{\mathrm{p}} \mathrm{x}_{\mathrm{i}}-\mathrm{pk}
$$

where $S_{p}$ is the cum-sum value, $x_{i}$ the $i^{\text {th }}$ observation and $k$ the mean of the series

\section{Results}

\subsection{Oceanographic conditions}

The monthly values of SST and chlorophyll calculated over the period 1997-2003 show clear seasonal signals (Figure 2). The SST data show two well marked seasons and short transition periods, with the coldest period during austral winter, the hottest during austral summer and temperatures increasing with latitude from the south of the Mozambique Channel to the north of the Seychelles Archipelago. Over the study period, the amplitude of the seasonal cycle, calculated from the differences of SST for successive months (i.e., monthly variations), does not differ significantly between locations (all test $t, p>0.05$ ). However, it could be noted that the waters surrounding Europa Island have slightly greater short-term variation (intra-monthly) and seasonal change in temperature than the 3 other locations. In the same way, Lys and Bird Islands have smaller short-term variation and seasonal amplitude, respectively.

Although seasonal cycles in chlorophyll occurred, they are independent of the latitude (Figure 2). Around both Europa and Bird Islands, which are the furthest apart, a bloom of phytoplankton starts in early winter and reaches a maximum in mid to late winter. This annual peak of chlorophyll is more marked around Bird Island than Europa Island. In addition to having their greatest seasonal variability, waters surrounding Bird Island have a greater interannual variability. Around Juan de Nova, over the year, the chlorophyll concentration is higher than around the other locations and shows two distinct periods. Between January and May (i.e. summer), when the SST are the warmest, the chlorophyll concentration is higher than during the second part of the year. Around Lys Island the concentration of chlorophyll is highest in late winter, and the seasonal peak of chlorophyll lasts longer than around the other islands.

\subsection{Sooty tern breeding phenology in relation to the marine environment}

Our data on laying dates for the sooty terns are highly correlated between years for Europa (all Spearman correlation rank rs, $\mathrm{p}<0.001$ ) and Juan de Nova ( $\mathrm{rs}=0.98, \mathrm{p}<0.001$ ) but at the limit of the threshold of significance for Lys $(r s=0.68, p=0.048)$. Table 1 shows the mean laying peak by island and year, and the time lag between successive mean peaks of laying. The small difference in dates between two successive laying peaks at Europa and Juan de Nova Islands indicates seasonal reproduction, which also occurs at Bird Island (Feare 1976, 1981). On the other hand, the time lag between successive years in the mean laying dates at Lys Island is higher and close to one month (32 days). This result suggests a nonseasonal breeding regime there, as reinforced by previous observations (Table 1).

As expected, the analysis of the trend in the time series of SST and chlorophyll concentration indicates seasonal signals around all islands. Results of this analysis, however, give new information on the variability of the marine environment around the breeding locations. Hence, during periods with laying data for Europa, Juan de Nova and Bird Islands, the results reveal a clear and evident relation between laying dates and both SST and chlorophyll (Figure 3). The laying begins on average one month after the change of trend in the SST, and the chlorophyll trend reaches a maximum a short time after the laying period. In all cases, this maximum corresponds to the highest peak of chlorophyll during the year. An interesting difference between these locations is that the trends of SST and chlorophyll concentration are in opposition at Europa and Bird Islands, whereas they are in phase at Juan de Nova, with a slight lag in the response of the chlorophyll compared to the SST in all the 
cases. This result confirms the difference of regime in the productivity of these oceanic areas, already noted previously, but also the relation between the SST and the concentration of chlorophyll. In 2003, around Lys Island, SST and chlorophyll also showed seasonal trends and relation between the two parameters. However, there is no clear relation between the laying period and the variation of the marine environment (Figure 3).

\section{Discussion}

The oceanographic conditions around the sites we studied are different but show marked seasonal signals characterized in particular by annual blooms of phytoplankton. These blooms are suitable for the aggregation of zooplankton, small nekton, and larger carnivorous nektonic species (Piontkovki and Williams 1995) that are preyed on by top predators like seabirds. Our study demonstrates that the timing of reproduction of the sooty terns in the southwest Indian Ocean matches with these seasonal peaks of chlorophyll, except at Lys Island. In all the cases, the peaks of chlorophyll follow significant variations of SST, themselves induced by seasonal changes of the marine environment. Thus we suggest that the seasonal breeding regime at Europa, Juan de Nova and Bird Islands is driven by climate signals that strongly modify the marine environment and lead to favourable distribution of food around the breeding sites. Conversely, the non-seasonal breeding regime suspected at Lys Island (Le Corre \& Jaquemet 2005) and exhibited in this study occurs when seasonal changes of the environment do not significantly affect the aggregation of organisms preyed on by sooty terns around the island.

\subsection{Local environmental variations}

We clearly identify a correlation between the breeding season of sooty terns from Europa, Juan de Nova and Bird Islands and the seasonal variability of the local marine environment as was already demonstrated for other species at different latitudes (Forchhammer et al 1998, Ramos et al 2002, Frederiksen et al 2004). The relatively rapid variation in SST (change of trend) before the beginning of the reproduction indicates strong modification of the environment, which precedes the increase in marine productivity. This situation favours prey concentration and acts as the starter of the breeding period for sooty terns. The maximum of productivity is reached after the laying peak, during the rearing period, when the requirements of food for the colonies are the highest. In other tropical areas like the Galapagos Archipelago, a correlation between the change of SST and the breeding activity has already been reported (Boersma 1978). These strong modifications of the environment revealed by the SST are often favourable to the enhancement of productivity of the ocean. Although the SST and the chlorophyll concentration around Lys Island show seasonal signals similar to those observed at the other locations, they do not seem to induce a seasonal breeding regime there. This suggests that they do not induce sufficiently favourable seasonal conditions to optimise the breeding success of the terns, or that there is no reliable proximal cue for conditions when young will be present. Such a situation is similar to that observed at Ascension Island in the equatorial Atlantic Ocean, where sooty terns breed independently of the seasonal variation in the environment and breed approximately every 10 months (Ashmole 1963).

Sooty terns are commensal of surface schools of tuna (Schreiber et al 2002), and an increase in fish catches could be expected during the breeding seasons. However, surprisingly, the main catches of surface tropical tuna around the colonies do not closely match the breeding activity of the sooty terns (i.e., Marsac 1992, Fonteneau 1997). In winter, the main fishing activity of the studied area is centred on the Somalia upwelling, north of Bird Island. In the northern part of the Mozambique Channel, the fishing of surface tuna occurs between January and May, and the activity moves southward during this period. It is centred on the Juan de Nova sector after the breeding period of the terns (April-May). In both cases, 
however, the density of schools of tuna may be high enough for terns. It is quite likely that there is only a weak connection between fishing statistics and the real abundance of tuna. In the south of the Mozambique Channel, the commercial fishing activity is almost non-existent, but a survey has demonstrated a strong association between surface schools of predators, including tuna and sooty tern flocks during their breeding period (Jaquemet et al 2005), suggesting high tuna abundance.

\subsection{Seasonal breeding regime and large-scale variability of the marine environment}

The seasonal variability of the marine environment at coarse scale $(500 \mathrm{~km})$ around the breeding sites is as well marked as that observed in the tropical western Indian Ocean, which is under the control of the monsoon phenomenon and the southern climate (Donguy \& Meyers 1996). Hence, the contrasted breeding regimes between Europa and Bird Islands on the one hand and Juan de Nova on the other seem to be consequences of the seasonal variation of the oceanic conditions in the area and the development of oceanic structures that favour the aggregations of marine organisms, including prey and commensal surface tuna.

In austral winter in the southern Mozambique Channel and in the north of the Seychelles Archipelago, the intensification and the northward drift of the Subtropical Convergence (Villacastin-Herrero et al 1996) and the activation of the southwest monsoon (Cushing 1971) respectively, favour mixing of the euphotic layer leading to a decrease of SST and an increase of sea-surface salinity (Donguy \& Meyers 1996). These conditions allow the development of phytoplankton blooms highlighted by the peaks of chlorophyll. In the sea around the Seychelles, consequently, primary, secondary, and tertiary production are higher between May and October than during the November-March period (Cushing 1971, Feare 1981), and such processes probably also occur around Europa Island. These blooms, therefore, tend to induce the aggregation of marine organisms like flying fish (Piontkovki and Williams 1995), which are largely preyed on by sooty terns of these islands (Feare 1976, Jaquemet unpubl. data). The result is a large amount of food available around the colonies for breeding seabirds, which are limited in their foraging range (Flint 1991). The plentiful catches of pelagic fishes observed south of the Mozambique Channel and Madagascar (Le Corre 2001) reinforce the idea of a higher productivity of the marine environment at this season.

Although the summer seasonal reproduction of sooty terns on Juan de Nova was already known (Le Corre 2001), the size of the colony was only recently estimated (Le Corre $\&$ Jaquemet 2005). The breeding of this huge colony $(2,000,000$ breeding pairs, the largest of the Indian Ocean) in austral summer, in the warm pool of the southwest Indian Ocean (Donguy \& Meyers 1996), suggests a large amount of food available at this season in the surface layer. Although SST and chlorophyll are usually negatively correlated, the peak in chlorophyll and the plentiful long-line catches of tuna for the area (Fonteneau 1997) confirm the probably large availability of food in the vicinity of the island. These observations suggest particular ocean forcing that induces favourable conditions for the development of large phytoplankton biomass. It has been recently demonstrated that around five anticyclonic eddies per year pass through or form at the narrows of the Channel (Ridderinkhof and de Ruitjer 2003). This southward train of eddies has maybe led previous researchers to infer a small cyclonic eddy centred on the Davie Ridge in summer (Saetre and Jorge da Silva 1984) and could explain the divergence of currents found by Piton and Magnier (1976). The interactions of these features advect water into the central part of the Channel and also lead to upwelling and enhancement of the biological production (McGillicuddy et al 1998, Lima et al 2002). Anticyclonic structures favour the aggregation and the development of zooplanktonic organisms by generating retention of phytoplankton biomass (Lima et al 2002) and passive drifting organisms like larvae, and such an effect is corroborated by the numerical dominance of fish larvae and post-juveniles in the diet of the sooty terns of Juan de Nova (Jaquemet unpubl. data). Finally, since Juan de Nova is on the edge of the continental shelf, the outflows 
of the Madagascan rivers during the rainy season (November to March, Jury \& Pathack 1991) could increase the input of nutrients on to the shelf and also favour primary production.

\subsection{Non-seasonality of Lys Island breeding regime}

Conversely to Europa, Juan de Nova and Bird Islands, which are located in seasonally productive areas induced by large-scale oceanic forcing, Lys Island is less affected by major oceanic variations. The island, indeed, is south of the south-equatorial divergence, north of the Mozambique Channel circulation and far from seasonally existing oceanic features such as fronts or upwellings (Piton \& Magnier 1976). Moreover, the island is on the path of the northern branch of the SEC all year round. This leads to a more extended primary production period with a less marked temporal variation than at southern and northern locations. Such a situation is probably responsible for a greater unpredictability of the optimal oceanic conditions to breed and for irregular fluctuations of the feeding opportunities all year round. This could explain the non-seasonal breeding regime there. Indeed, if seasonal changes occurred but have rather little effect on breeding success at different times of the year, breeding at less than annual intervals might be advantageous for sooty terns (Ashmole 1963). In this case the marine environment has favoured individuals that attempt to breed as often as they can, and it could explain the non-seasonality of the breeding regime of the sooty terns already noted at Lys Island (Diamond \& Prys-Jones 1986, Le Corre 2001, Le Corre \& Jaquemet 2005). A similar situation in the breeding regime also occurs in the Seychelles Archipelago with a closely related species, the bridle tern (Sterna anaethetus), which breeds every 8 months at Cousin Island (Diamond 1976). However the reasons why bridled terns breed every 8 months at a place where most other seabird species breed seasonally during austral winter is not known (Diamond 1976). Interestingly, the reproduction at Lys Island is synchronised, and the species is known to have little success with second nesting attempts if the first one fails (Feare 1976, Schreiber et al 2002). Similar observations have been reported for sooty terns on Ascension Island (Atlantic), which have a non-seasonal reproduction but co-ordinate their breeding (Ashmole 1963). This suggests that colonialism is a more important selective pressure than the food availability for the species. It has been proposed that the colonies may act as information centres, which help individuals to locate the sources of food (Ward \& Zahavi 1973). In the case of Lys Island, where the availability of prey may be hard to predict, colonialism may increase the breeding success of individuals. However, recent results do not support the information centre hypothesis (Davoren et al 2003). It has even been demonstrated that the size of the colony is negatively correlated to the foraging activity of individuals (Lewis et al 2001, Ainley et al 2003). On the other hand, sooty terns adopt a network foraging strategy at sea, which means cooperation (Jaquemet et al 2005). Hence, the high density of individuals may confer enough advantage in the search for food sources to outweigh the impact of intraspecific competition. Indeed, food resources are very patchy and mostly ephemeral in tropical oceanic waters, even when their production is at its highest.

These differences of reproductive strategies involve different life history traits between individuals of the populations. It shows the importance of intraspecific comparisons of the reproduction at different locations to understand the influence of the environment on the breeding, as already studied in the Southern Ocean on an albatross species (Pinaud \& Weimerskirch 2002).

In conclusion, we suggest that there is oceanic control of the breeding phenology of the sooty terns of the southwest Indian Ocean. When the marine environment surrounding the colonies is seasonal and leads to the development of predictable oceanic features aggregating prey such as fronts, seasonal reproduction occurs. Conversely, when the seasonality of the marine environment does not lead to development of such features, non-seasonality of reproduction occurs. This hypothesis is reinforced by the seasonal reproduction, during winter, at Cosmoledo Atoll $\left(9^{\circ} 43^{\prime} \mathrm{S}, 47^{\circ} 35 \mathrm{E}\right.$, Figure 1) of a huge sooty tern colony 
(Rocamora et al 2003) in the southern part of the Seychelles Archipelago. Indeed, during the breeding period, the colony is on the edge of the divergence between the SEC and the Equatorial Counter Current (Piton \& Magnier 1976).

In the light of our results and in the context of climate change, we could ask how sooty terns are able to respond to large climatic fluctuations of the ocean like El Niño Southern Oscillation. Indeed, several studies have already demonstrated the influence of large-scale weather events on the reproductive performances and dynamics of animal populations in different locations (Schreiber \& Schreiber 1984, Forchhammer et al 1998, Post \& Forchhammer 2002, Ramos et al 2002, Frederiksen et al 2004). Further studies will help discern the advantages and disadvantages of seasonal and non-seasonal reproduction regime in response to unpredictable climatic fluctuations. Conversely, the breeding biology of seabirds could be useful to monitor changes of long-term environmental conditions.

\section{Acknowledgements}

The field work was supported financially by the DIREN-Réunion and logistically by the FAZSOI, to whom we are grateful. SJ benefited from a $\mathrm{PhD}$ grant from the French Ministère de l'Enseignement Supérieur de la Recherche. Help on field work from M. Salamolard, M. Charrier, F. Saint-Ange, T. Gesthemme S. Caceres, E. Robert and J. Emeras is appreciated. We are indebted to F. Marsac and A. Fonteneau from IRD-UR Thétis and the IOTC for their constructive comments on the manuscript. SeaWiFS data were processed and provided by NASA/GSFC under the 'Mission to Planet Earth', with data management at NOCS by L. Marsh. Comments by R. Wynn on an early draft are greatly appreciated, as are constructive comments from 3 anonymous reviewers.

\section{References}

Ainley, D.G., Boekelheide, R.J., 1990 Seabirds of the Farallon Islands. Stanford, CA: Stanford University Press

Ainley, D.G., Ford, R.G., Brown, E.D., Suryan, R.M., Irons, D.B., 2003 Prey resources, competition, and geographic structure Kittiwakes colonies in Prince William Sound. Ecology 84(3), 709-723

Anderson, D.W., Gress, F., Mais, K.F., 1982 Brown pelican: influence of food supply on reproduction. Oïkois 39, 23-31.

Arnoux, R., 1950 Rookery de sternes aux Glorieuses. La Naturaliste Malgache II-1

Ashmole, N. P. 1963 The biology of the wideawake or sooty tern Sterna fuscata on Ascension Island. Ibis 103b, 297-364.

Ashmole, N. P. 1971 Seabird ecology and the marine environment. In Avian Biology, vol. 1 (ed. D. S. Farner \& J. R. King), pp. 223-286. New-York.

Beebe, K., Bentley, G.E., Hau, M., 2005- A seasonally breeding tropical bird lacks absolute photorefractoriness in the wild, despite high photoperiodic sensitivity. Functional Ecology 19, 505-512

Benson, C.W., Beamish, H.H., Jouanin, C., Salvan, J., Watson, G.E., 1975 The Birds of the Iles Glorieuses. Atoll Research Bulletin 176, 1-33

Boersma, P.D., 1978 Breeding patterns of Galapagos Penguins as indicator of oceanographic conditions. Science 200, 1481-1483

Cairns, D. K., 1992 Population regulation of seabird colonies. New-York: M. Power.

Chastel, O., Weimerskirch, H., Jouventin, P., 1995 Body condition and seabird reproductive performance: A study of three petrel species. Ecology 76, 2240-2246.

Cruz, J.B., Cruz, F., 1990 Effect of El-Nino Southern Oscillation conditions on nestling growth rate in the dark-rumped petrel. The Condor 92, 160-165

Cushing, D. H., 1971 Survey of resources in the Indian Ocean and Indonesian sea, pp. 1-123. Rome: Indian Ocean Fishery Commission FAO. 
Davoren, G.K., Montevecchi, W.A., Anderson, J.T., 2003 Search strategies of a pursuitdiving marine bird and the persistence of prey patches. Ecological Monograph 73, 463-481

de Ruijter, W. P. M., Ridderinkhof, H., Lutjeharms, J. R. E., Schouten, M. W., Veth, C. 2002 Observations of the flow in the Mozambique Channel. Geophysical Research Letters 29, 1-4 doi. 10.1029/2001GL013714.

Di Marco, S. F., Chapman, P., Nowlin, W. D. J., Hacker, P., Donohue, K., Luther, M., Johnson, G. C., Toole, J. 2002 Volume transport and property distributions of the Mozambique Channel. Deep-Sea Research II 49, 1481-1511.

Diamond, A. W., 1976 Subannual breeding and moult cycles in the Bridled tern (Sterna anaethetus) in the Seychelles. Ibis 118, 414-419.

Diamond, A. W., Prys-Jones, R. P., 1986 The biology of terns nesting at Aldabra Atoll, Indian Ocean, with particular reference to breeding seasonality. Journal of Zoology of London 210, 527-549.

Donguy, J. R., 1974 Une année d'observations de surface dans la zone de mousson de la partie occidentale de l'océan Indien. Cahier ORSTOM (Série Océanographie) 12, 117-118.

Donguy, J. R., Piton, B., 1991 The Mozambique Channel revisited. Oceanologica Acta 14, 549-558.

Donguy, J. R., Meyers, G., 1996 Seasonal variations of sea-surface salinity and temperature in the tropical Indian Ocean. Deep-Sea Research I 43, 117-138.

Feare, C. J., 1976 The biology of the Sooty tern Sterna fuscata in the Seychelles and the effects of experimental removal of its eggs. Journal of Zoology of London 179, 317360.

Feare, C. J., 1981 Breeding schedules and feeding strategies of Seychelles seabirds. Ostrich 52, 179-185.

Flint, E. N., 1991 Time and energy limits to the foraging radius of Sooty Terns Sterna fuscata. Ibis 133, 43-46.

Fonteneau, A., 1997 Atlas of tropical tuna fisheries. World catches and environment. Paris, Orstom editions

Forchhammer, M. C., Post, E., Stenseth, N. C., 1998 Breeding phenology and climate. Nature 391, 29-30.

Frederiksen, M., Harris, M. P., Daunt, F., Rothery, P., Wanless, S., 2004 Scale-dependent climate signals drive breeding phenology of three seabirds species. Global Change Biology 10, 1214-1221.

Hamer, K.C., Schreiber, E.A., Burger, J., 2002 Breeding biology, lifes histories, and life history-environment interactions in seabirds. Biology of marine birds, Bocan Raton: CRC Press

Harrison, C. S., Hida, T. S., Seki, M. P. 1983 Hawaiian seabird feeding ecology. Wildlife Monography 85, $71 \mathrm{pp}$.

Hyrenbach, D.K., Veit, R.R., 2003 Ocean warming and seabird communities of the California Current System: response at multiple temporal scales. Deep-Sea Research I, 50 (1416), 2537-2565

Ibanez, F., Fromentin, J. M., Castel, J., 1993 Application de la méthode des sommes cumulées à l'analyse de séries chronologiques océanographiques. Comptes Rendus de l'Académie des Sciences de Paris, Sciences de la Vie/Life Sciences 316.

Jaquemet, S., Le Corre, M., Marsac, F., Potier, M., Weimerskirch, H., 2005 Foraging habitat of the seabird community of Europa Island (Mozambique Channel). Marine Biology 147(3), 573-582

Jury, M.R., Pathack, B., 1991 A study of climate and weather variability over the tropical southwest Indian Ocean. Meteorology and Atmospheric Physics, 47(1), 37-48

Lack, D., 1968 Ecological adaptations for breeding in birds. London: Methuen. 
Le Corre, M., 2001 Breeding seasons of seabirds of Europa Island (southern Mozambique Channel) in relation to seasonal changes in the marine environment. Journal of Zoology of London 254(2), 239-249.

Le Corre, M., Cherel, Y., Lagarde, F., Lormée, H. \& Jouventin, P., 2003 Seasonal and interannual variation in the feeding ecology of a tropical oceanic seabird, the red-tailed tropicbird Phaethon rubricauda. Marine Ecology Progress Series 255, 289-301.

Le Corre, M., Jaquemet, S., 2005 Assessment of seabird community of the Mozambique Channel and its potential use as indicator of tuna abundance. Estuarine Coastal and Shelf Sciences 63, 421-428.

Lewis, S., Sherratt, T.N., Hamer, K.C., Wanless, S., 2001 Evidence of intra-specific competition for food in a pelagic seabird. Nature 412, 816-819

Lima, I. D., Olson, D. B., Doney, S. C., 2002 Biological response to frontal dynamics and mesoscale variability in oligotrophic environments: Biological production and community structure. Journal of Geophysical Research 107, (C8):10.1029/2000JC000393.

Lindberg, M. S., Sedinger, J. S., Flint, P. L., 1997 Effects of spring environment on nesting phenology and clutch size of Black Brant. The Condor 99, 381-388.

Lormée, H., Jouventin, P., Lacroix, A., Lallemand, J., Chastel, O., 2000 Reproductive endocrinology of tropical seabirds: sex-specific pattern in LH, steroids, and prolactin secretion in relation to parental care. General Comparative Endocrinology 117, 413-426

Marsac, F., 1992 Etude des relations entre l'hydroclimat et la pêche thonière hauturiere tropicale dans l'océan Indien occidental. $\mathrm{PhD}$ thesis Océanographie Biologique, pp. 353. Brest- France: Université de Bretagne occidentale.

Martin, T. E., 1987 Food as limit on breeding birds: a life-history perpective. Annual Review of Ecological Systems 18, 453-487.

McGillicuddy, D. J. J., Robinson, A. R., Siegel, D. A., 6 others, 1998 Influence of mesoscale eddies on new production in the Sargasso Sea. Nature 394, 263-266.

Parrish, J. K., Lemberg, N., South-Oryshchyn, L., 1998 Effects of colony location and nekton abundance on the at-sea distribution of four seabird species. Fisheries Oceanography 7, 126-135.

Peck, D.R., Smithers, B.V., Krockenberger, A.K., Congdon, B.C., 2004 Sea-surface temperature constraints wedge-tailed shearwater foraging success within breeding seasons. Marine Ecology Progress Series 281, 259-266

Pinaud, D., Weimerskirch, H., 2002 Ultimate and proximate factors affecting the breeding performance of a marine top-predator. Oikos 99, 141-150.

Piontkovski S.A., Williams R., 1995 Multiscale variability of tropical ocean zooplankton biomass. ICES J Mar Sci 52:643-656

Piton, B., Magnier, Y., 1976 Les conditions favorables à la présence de thons de surface dans les parages de Madagascar. Travaux et Documents de L'ORSTOM 47, 293-309.

Post, E., Forchhammer, M. C., 2002 Synchronization of animal population dynamics by large-scale climate. Nature 420, 168-171.

Quartly, G. D., Srokosz, M. A., 2004 Eddies in the southern Mozambique Channel. Deep-Sea Research II 51, 69-83.

Ramos, J. A., Maul, A. M., Ayrton, V., Bullock, I., 5 others, 2002 Influence of local and large-scale weather events and timing of breeding on tropical roseate tern reproductive parameters. Marine Ecology Progress Series 243, 271-279.

Ridderinkhof, H., de Ruijter, W. P. M., 2003 Moored current observations in the Mozambique Channel. Deep-Sea Research II 50, 1933-1955.

Rocamora, G., Feare, C., Skerrett, A., Athanase, M., Greig, E., 2003 The breeding avifauna of Cosmoledo Atoll (Seychelles) with special reference to seabirds: conservation status 
and international importance. Bird Conservation International 13, 151-174. DOI: $10.1017 / \mathrm{S} 0959270903003137$

Rocamora, G., Skerrett, A., 2001 Seychelles. In Africa and associated islands (ed. L. Fishpool and M. I. Evans), pp. 751-768. Newbury and Cambridge.

Saetre, R., Jorge da Silva, A., 1984 The circulation of the Mozambique Channel. Deep-Sea Research II 31, 508-585.

Schouten, M. W., de Ruijter, W. P. M., van Leeuwen, P. J., Ridderrinkohf, H., 2003 Eddies and variability in the Mozambique Channel. Deep-Sea Research II 50 1987-2003.

Schreiber, E.A., 2002 Climate and weather effects on seabirds. Biology of marine birds, Bocan Raton: CRC Press

Schreiber, R. W., 1980 Nesting chronology of the eastern brown pelican. Auk 97, 491-508

Schreiber, R. W., Schreiber, E. A., 1984 Central Pacific seabirds and the El Nino Southern Oscillation: 1982-1983 perspectives. Science 225 713-716.

Schreiber, E. A., Feare, C. J., Harrington, B. A., Murray, B. G. J., Robertson, W. B. J., Robertson, M. J., Woolfenden, G. E., 2002 Sooty Tern (Sterna fuscata). In The Birds of North America, vol. 665 (ed. A. P. a. F. Gills). Philadelphia, PA.

Shea, R. E., Ricklefs, R. E., 1996 Temporal variation in growth performance in six species of tropical, pelagic seabirds. Journal of Animal Ecology 65, 29-42.

Spear, L.B., Balance, L.T., Ainley, D.G., 2001 Response of seabirds to thermal boundaries in the tropical Pacific: the thermocline versus the Equatorial Front. Marine Ecology Progress Series 219, 275-289

Stequert, B., Marsac, F., 1986 La pêche de surface des thonidés tropicaux dans l'Océan Indien, vol. 282, pp. 1-213. Rome: FAO Document technique sur les pêches.

Swallow, J., Fieux, M., Schott, F., 1988 The boundary currents east and north of Madagascar 1.Geostrophic currents and transports. Journal of Geophysical Research 93, 49514962.

van der Elst, R., Prys-Jones, R.P., 1987 Mass killing by rats of roosting common noddies. Oryx 21: 219-222

Villacastin-Herrero, C. A., Underhill, L. G., Crawford, R. J. M., Shannon, L.V., 1996 Sea surface temperature of oceans surrounding subequatorial Africa: seasonnal patterns, spatial coherence and long-term trends. South African Journal of Sciences 92, 189197.

Ward, P., Zahavi, A., 1973 The importance of certain assemblages of birds as 'information centres' for food-finding. Ibis 115, 517-534

Wikelski, M, Hau, M., Robinson, W.D., Wingfield, J.C., 2003 Reproductive seasonality of seven neotropical passerine species. Condor 105, 683-695

Wingfield, J.C., Kenagy, G.J., 1991 Natural regulation of reproductive cycles. Vertebrate Endocrinology: Fundamentals and Biomedical Implications. Academic Press, New York

Zubkov, M. V., Quartly, G. D., 2003 Ultraplankton distribution in the surface waters of the Mozambique Channel - flow cytometry and satellite imagery. Aquatic Microbial Ecology 33 155-161. 
Click here to download Figure: Figure 1.doc
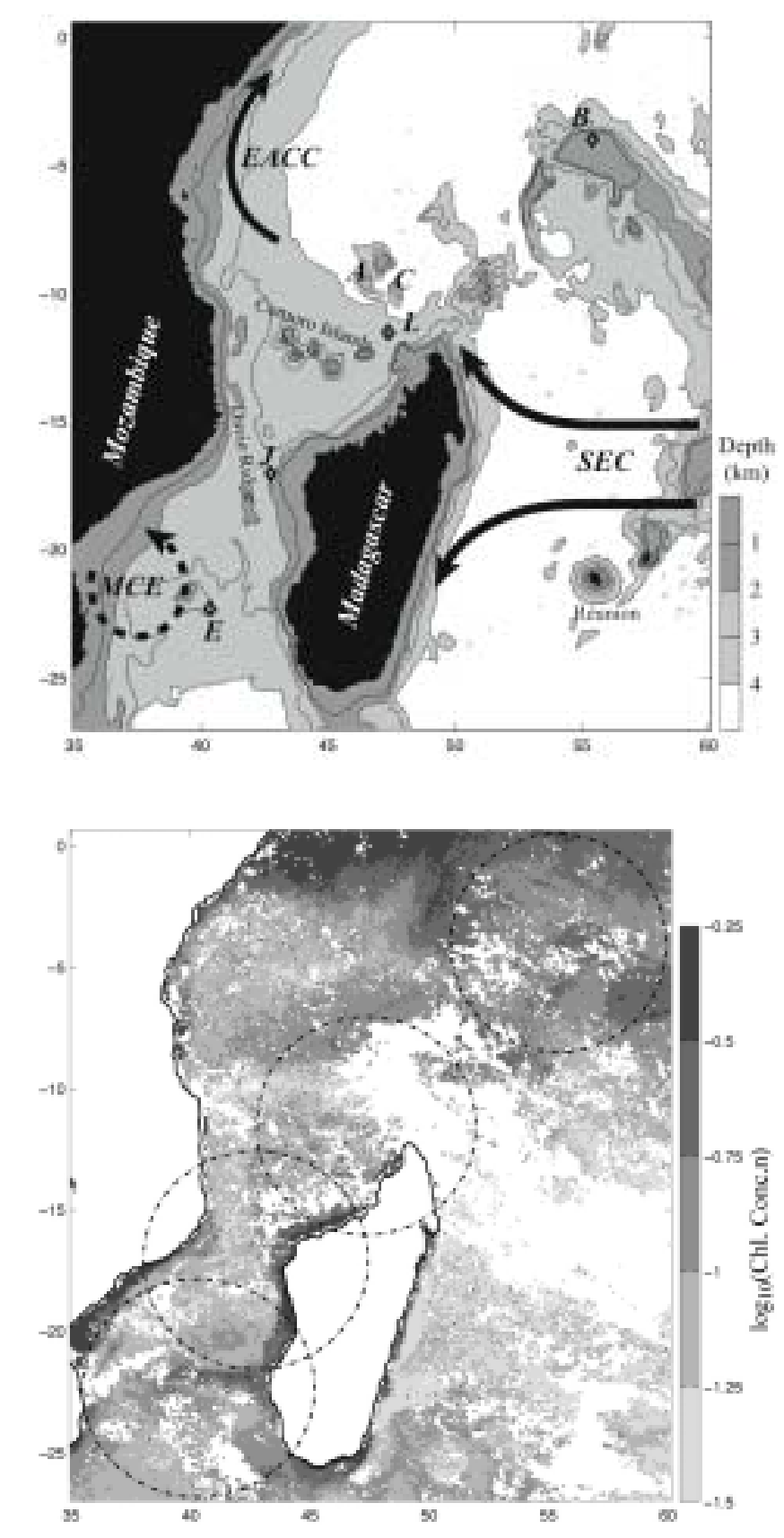

Figure 1 

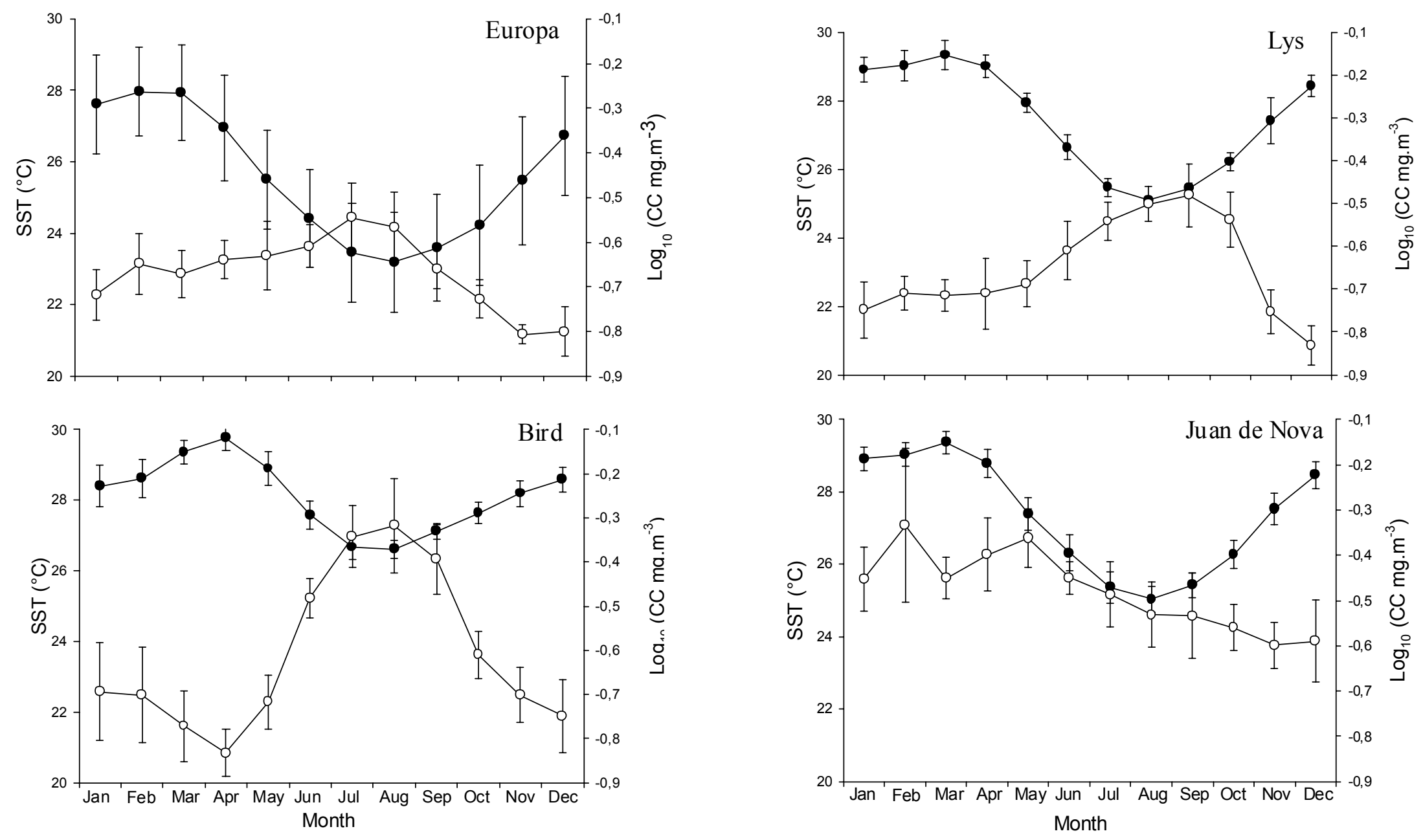


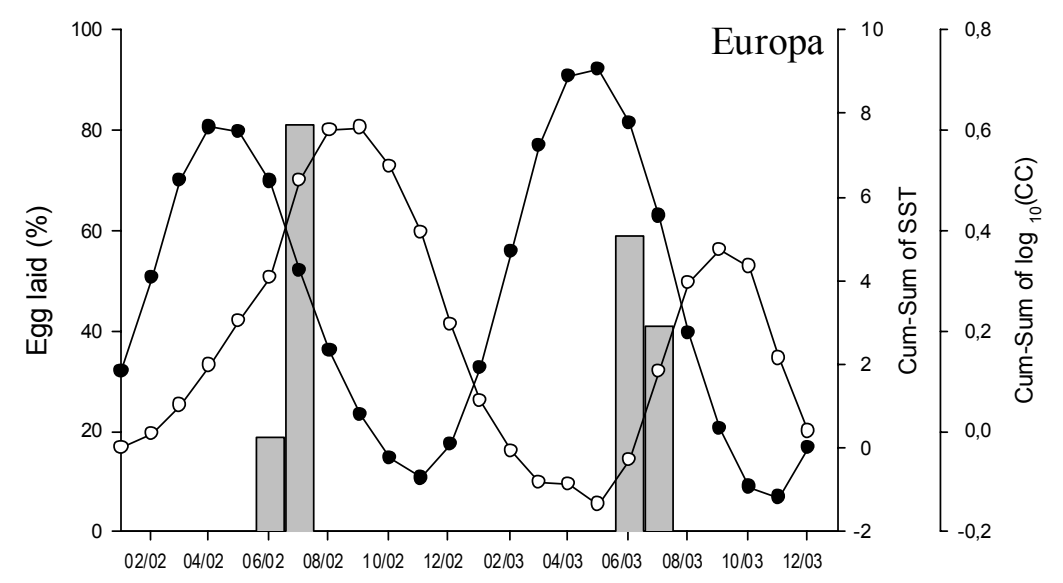

Date

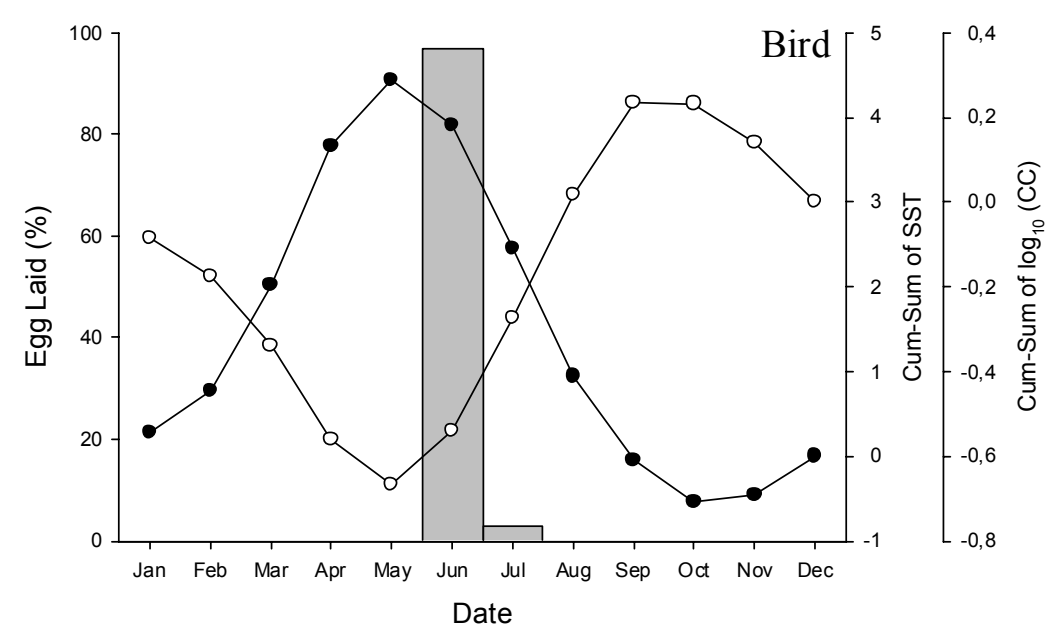

Figure 3
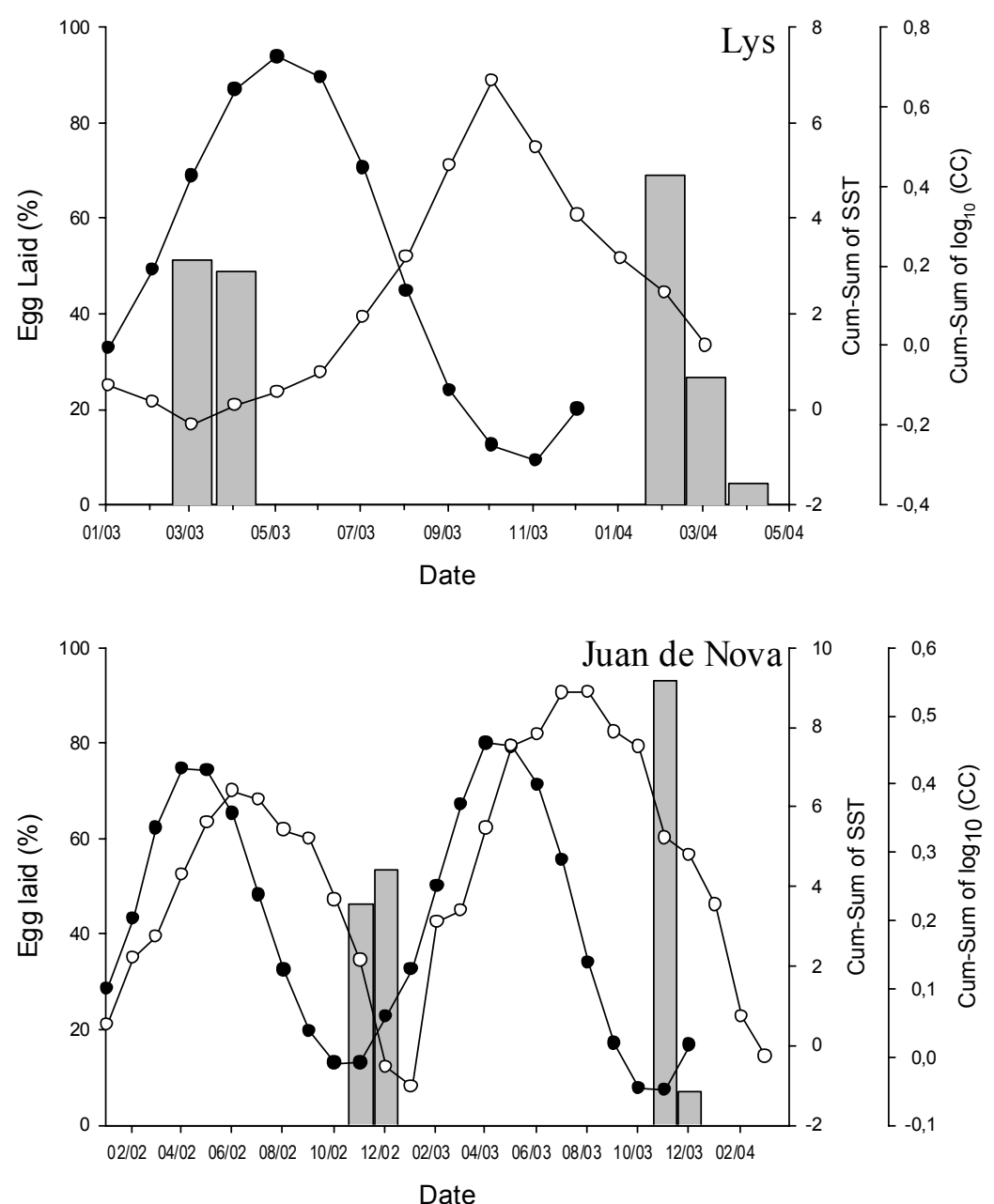
Table 1-Mean laying date of sooty terns according to breeding site

\begin{tabular}{|c|c|c|c|c|}
\hline Breeding site & Year & $\mathrm{N}$ & $\begin{array}{l}\text { Mean laying date } \\
\pm \text { SD (day) }\end{array}$ & $\begin{array}{c}\text { Difference between } 2 \text { successive } \\
\text { mean laying date (day) }\end{array}$ \\
\hline \multirow{4}{*}{ Europa } & 1995 & 146 & $10 / 07 \pm 9$ & \\
\hline & 2002 & 211 & $03 / 07 \pm 8$ & \\
\hline & 2003 & 155 & $29 / 06 \pm 5$ & 4.5 \\
\hline & 2004 & 146 & $30 / 06 \pm 4$ & -2.1 \\
\hline \multirow{2}{*}{ Juan de Nova } & 2003 & 140 & $06 / 12 \pm 11$ & \\
\hline & 2004 & 38 & $24 / 11 \pm 5$ & 12.8 \\
\hline \multirow{6}{*}{ Glorieuses } & 2003 & 78 & $01 / 04 \pm 6$ & \\
\hline & 2004 & 177 & $29 / 2 \pm 11$ & 31.7 \\
\hline & $1993^{\mathrm{a}}$ & & October & \\
\hline & $1985^{\mathrm{b}}$ & & March & March, no breeding sooty terns \\
\hline & $1970^{\mathrm{c}}$ & & August & \\
\hline & $1948^{\mathrm{d}}$ & & February & \\
\hline Bird Island & $1976^{\mathrm{e}}, 1981^{\mathrm{f}}, 2001^{\mathrm{g}}$ & & June & \\
\hline
\end{tabular}

a: J. Guyon pers. comm., b: van der Elst \& Prys-Jones 1987, c: Benson et al 1975, d:

Arnoux 1950, e: Feare 1976, f: Feare 1981, g: Rocamora \& Skerrett 2001 